Przemysław Turek

Jagiellonian University in Kraków

\title{
Syriac Heritage of the Saint Thomas Christians: Language and Liturgical Tradition
}

\section{Saint Thomas Christians - origins, language and liturgy}

According to the anonymous Syriac apocryphal Acts of Thomas from the first half of the $3^{\text {rd }}$ century, the apostolic mission to India began during the first half of the first century CE. Thomas the Apostle himself is supposed to bring the Gospel to India's king and eventually to die as a martyr in South India near Madras. ${ }^{1}$

As mentioned in the Indian tradition, St Thomas did not travel directly to Madras but made landfall in the coastal region of Kerala. ${ }^{2}$ The historical sources mentioned the existence of an ancient group of Christians from Kerala, traditionally called Saint Thomas Christians, since the end of the $2^{\text {nd }}$ century. ${ }^{3}$ We have no detailed information about Christianity in Kerala in the first three centuries. One could only speculate what language was used in prayers (most probably Aramaic, and later Syriac), what the early liturgy looked like (doubtless similar to the early Christian one). In the course of time the community had to pass through many difficulties primarily due to the lack of ecclesiastical assistance from the mother Church. ${ }^{4}$

\footnotetext{
${ }^{1}$ Apocryphal Acts of the Apostles, Edited from Syriac Manuscripts in the British Museum and Other Libraries by W. Wright. Vol. I. The Syriac Texts. Vol. II. The English Translation, Piscataway, New Jersey 2005, I, pp. محس-على, II, pp. 146-298.

${ }^{2}$ C. Baumer, The Church of the East. An Illustrated History of Assyrian Christianity, London-New York 2008, p. 26.

${ }^{3}$ Ibidem; cf. A. S. Atiya, Historia Kościołów wschodnich, Warszawa 1978, p. 311 (Polish translation of A. S. Atiya, A History of Eastern Christianity, London 1968. The broader edition of this book was published in 1980).

${ }^{4}$ Church in Malankara (http://www.socmnet.org/ResourceMalankara.htm).
} 
The influence of the Syriac language could have increased with the new wave of immigrants from Syria in the year 345 AD. According to the tradition recorded in the $18^{\text {th }}$ century document, Thomas of Cana (கॅm) மி மேவ knâni tômâ), a prominent merchant, came with 72 families to the Malabar Coast. ${ }^{5} \mathrm{He}$ is supposed to have been accompanied by Bishop Joseph of Edessa who began the hierarchical integration of the Saint Thomas Christians with the Church of the East. ${ }^{6}$ Thus the early Christian converts (Saint Thomas Christians) as well as the new Christian settlers (Knanaya Christians) ${ }^{7}$ came to be known commonly as 'Syrian Malabar Christians' (or Nasrani). ${ }^{8}$

The liturgical language of the Saint Thomas Christians, at least from the first half of the $4^{\text {th }}$ century, must have been Syriac. Thus, even though Syriac was never the mother tongue of the Malabar Christians, they have known it longer than their own mother tongue Malayalam (developed between the $9^{\text {th }}$

${ }^{5}$ Thomas of Cana, a Nestorian from the Middle East is believed to have relocated to Kerala between the $4^{\text {th }}$ and the $8^{\text {th }}$ century. Cf. N. W. Pigulewska, Kultura syryjska we wczesnym średniowieczu [Syriac Culture in the Early Middle Ages]. Translation from the Russian by Czesław Mazur, Warszawa 1989, pp. 29-30 [a remark of the editor]; W. Baum, D. W. Winkler, The Church of the East. A concise history, London and New York 2003, p. 52; C. Baumer, op. cit., p. 28 : "The other dubious witness concerns a merchant, Thomas of Kana, who landed in Cranganore with 72 families in, depending on the source, 345, 754, 774 or 795." Cf. autem D. Babu Paul, The Syrian Orthodox Christians of St. Thomas, Cochin 1986, pp. 23-24: "This Thomas of Canae arrived at the Cranganore Bay and landed and saw and, from the cross they wore round the neck, recognized the Christians who were brought to follow Christ by the extortions of the apostle mar Thoma, and who in spite of the oppressions of the heathens and heathen sovereigns continued to remain in the True Faith without any deviation. He struck their acquaintance and asked them about their past particulars and learned that their grievance was very hard on account of the want of the priests and that the Church was, owing to that reason, in a tottering condition. On learning these particulars he thought the delay was improper and loading his ship with the pepper, etc., which he then could gather, sailed off, and by Divine Grace, reached Jerusalem without much delay, and communicated to the Venerable Catholicose of Jerusalem in detail all facts he had observed in Malayalam. And thereon, with the sanction of Eusthathius, patriarch of Antioch, 400 and odd persons, comprising men, women and boys, with Episcopa Joseph of Uraha and priests and deacons, were placed under the orders of the respectable merchant, Thomas of Canae, and sent off by ship to Malayalam, with blessing. | By the Grace of Almighty God all these arrived at Cranganore in Malayalam in the year 345 of our Lord, without experiencing any inconvenience or distress on the way" (http://moradaistudycenter.org/booksonline_21.html). Atiya dates this immigration as late as to the $8^{\text {th }}$ century (!), about 774 (A. S. Atiya, op. cit., p. 311)

${ }^{6}$ C. Baumer, op. cit., p. 26.

${ }^{7}$ There are many publications which discuss the supposed Jewish origin of the Knanaya

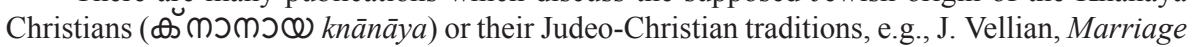
Customs of the Knanites, Christian Orient, 9, Kottayam 1988; C. A. Poomangalam, The Antiquities of the Knanaya Syrian Christians, Kerala 1998; J. Vellian, Knanite community: History and culture; Syrian Church Series, vol. XVII, Kottayam 2001.

${ }^{8}$ Church in Malankara, op. cit. 
and $10^{\text {th }}$ centuries). ${ }^{9}$ Syriac was the language of the liturgy and priests were expected to read and speak it. ${ }^{10}$ As Syriac was used during the formative period of Malayalam, numerous Syriac words are in use even today in Kerala. ${ }^{11}$ Even the name and title of Thomas the Apostle come from Syriac: மேைコว

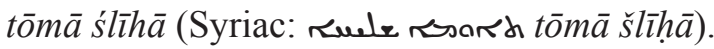

Although the linguistic situation of the community seemed rather clear, the above-mentioned relations with the Syriac speaking Church (Churches?) appeared more intricate. Even though the sources concerning the wave of Syriac immigrants are not the most reliable, one still believes that they followed (introduced?) the East Syrian Eucharistic Liturgy. The anaphora (கூశరు

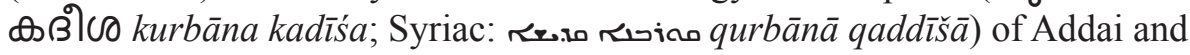
Mari is one of the oldest Eucharistic prayers in Christianity, possibly dating back to the $3^{\text {rd }}$ century Edessa. It does not only explicitly contain Words of Institution echoing those of Jesus himself spoken during the Last Supper, but it also encloses the pre-Ephesian Mariology. ${ }^{12}$

\section{Under the jurisdiction of the Church of the East}

At least from the first half of the $5^{\text {th }}$ century until the end of the $16^{\text {th }}$ century the bishops of the Church of Malabar recognized the supremacy of the (Nestorian) Church of the East and were sent from this Church. ${ }^{13}$

${ }^{9}$ R. E. Asher, T. C. Kumari, Malayalam, London and New York 1997, p. xxiii; L. J. Frohnmeyer, A Progressive Grammar of the Malayalam Language. Second edition, revised, New Delhi 2004 (originally published in 1913), p. xi; R. F. Moag, Malayalam. A University Course and Reference Grammar, Ann Arbor 1980, p. iii.

${ }^{10}$ D. Babu Paul, The Syrian Orthodox Christians of St. Thomas, Cochin 1986, p. 11: "Even in India the priests were well versed in Syriac," p. 29: "There was at least one Indian student of theology in the early days. A Syriac commentary on the translation of an epistle retains a note: 'This epistle has been translated from Greek into the Syriac by Mar Komai with the help of Daniel, the Indian priest.' This was in A.D. 425." Compare the liturgical booklet edited by the Carmelites in Malabar in 1887 (78 pp., the text given in East Syriac version, including script):

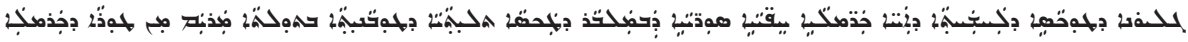

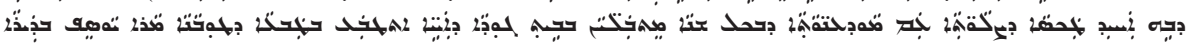

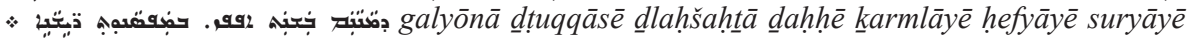

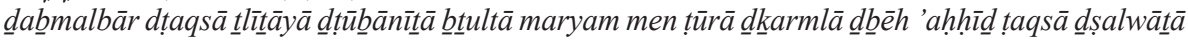

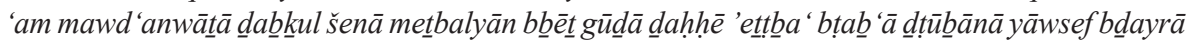
ḋmānānam bašnat 1887 bmappsānūt rēšānē.

${ }^{11}$ L. J. Frohnmeyer, op. cit., p. 284.

${ }^{12}$ Based on: B. Nadolski SJ, Liturgika. Vol. 1: Liturgika fundamentalna, Poznań 1989. Vol. 2: Liturgia i czas, Poznań 1991. Vol 3: Sakramenty, sakramentalia, błogosławieństwa, Poznań 1992. Vol. 4: Eucharystia, Poznań 1992. Information about Addai and Mari liturgy: Nadolski, op. cit., vol. 1, p. 38, vol. 4, pp. 29-30; A. G. Martimort, I. H. Dalmais, P.-M. Gy, P. Jounel, The Church at Prayer: Principles of the Liturgy, Collegeville, Minnesota 1987, pp. 29-31.

${ }^{13}$ A. S. Atiya, op. cit., pp. 311-313. 
In $\mathrm{AD} 410$, the Synod of the Churches in Persia was held, which recognized the primacy of the Metropolitan of Seleucia for the first time. ${ }^{14}$ Mār 'Isḥāq was approved $^{15}$ as Bishop of Seleucia-Ctesiphon, Catholicos and Archbishop of the entire East. ${ }^{16}$ The connection between the (Nestorian) Church of the East and the Saint Thomas Christians was formalized most probably around 410 or 420 with the creation of the Metropolitan See of Rev Ardashir. The See had jurisdiction over the Indian dioceses. ${ }^{17}$

In the year 650 the Metropolitan See of India was created under the direct authority of Patriarch Ishoyahb III. ${ }^{18}$ The see remained under the jurisdiction of the Patriarch of the Church of the East.

\section{The Portuguese in Malabar and the Latinisation of the Saint Thomas Christians}

The creation of the Portuguese trading settlements in India did not change the relationships between the local Saint Thomas Christians and the Portuguese, represented by merchants and Catholic clergy, who at first were not even versed in Syriac. For more than three decades the local Christians could retain their religious identity. Unfortunately, the arrival of the Jesuits resulted in the persecutions of Nestorians, the forced conversions to Catholicism and creation of concurrent Catholic Church supported by the Inquisition. When a part of the Mesopotamian Church entered into union with Rome in 1553, in the second half of the $16^{\text {th }}$ century there were three opponent hierarchies in India: the Nestorian, the Chaldean Catholic and the Roman Catholic. ${ }^{19}$

The Catholic archbishop of Goa Alexis de Menzes, appointed in 1597, decided to avoid a schism and to latinicise the Saint Thomas Christians. He

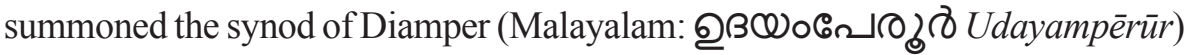
in June 1599, which, speaking briefly, resulted in the closure of the last exterior

${ }^{14}$ W. Baum, D. W. Winkler, op. cit., pp. 15-17, 20.

${ }^{15}$ He was elected in 399 (N. W. Pigulewska, op. cit., p. 228).

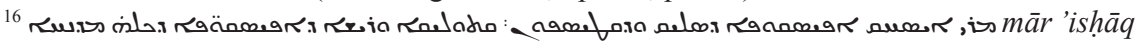

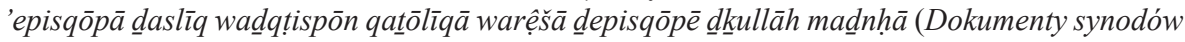
od 381 do 431 roku. Układ i opracowanie: A. Baron, H. Pietras SJ, Synody i Kolekcje Praw. Vol. IV, Źródła Myśli Teologicznej, Kraków 2010. Acta synodalia ab anno 381 ad annum 431. Compositio et elaboratio: Arcadius Baron, Henricus Pietras SJ, Synodi et collectiones legum. Vol. IV, Cracoviae MMX, p. 166).

${ }^{17}$ C. Baumer, op. cit., p. 26 ; cf. N. W. Pigulewska, op. cit., p. 61.

${ }^{18}$ This was the consequence of the disagreement between the patriarch and the disobedient metropolitan of Rev Ardashir, Shimun (C. Baumer, op. cit., p. 29; N. W. Pigulewska, op. cit., pp. 248-250; W. Baum, D. W. Winkler, op. cit., pp. 54-55).

${ }^{19}$ W. Baum, D. W. Winkler, op. cit., p. 113; C. Baumer, op. cit., p. 238. 
Nestorian see and the cultural destruction of the old Christian tradition, which had lasted for at least 13 hundred years. ${ }^{20}$

Paradoxically, the Catholic determination to avoid one schism led to another. A part of the persecuted Saint Thomas Christians, under the leadership of Archdeacon Thomas, revolted demanding from the Nestorian, Jacobite and Coptic patriarchs to send a non-Latin bishop. ${ }^{21}$ The opposition culminated in gathering at the Church of Our Lady in Mattancherry (Malayalam: ๑కુஸேினி mattannceri) on 3 January 1653 to swear what came to be known the Coonan

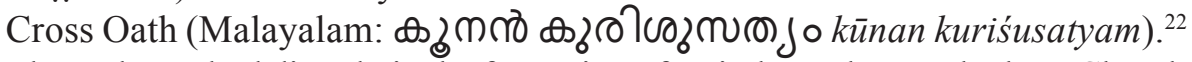
The oath resulted directly in the formation of an independent Malankara Church with Mar Thoma I (who was the former archdeacon as mentioned above) as her head from 1665. He was consecrated by the Syrian Orthodox Bishop Mor Gregorius. The Nestorian rite was replaced by the Jacobite one. The $1653 / 1665$ split into Catholic Syro-Malabar and Orthodox Malankara divisions was to be permanent; but there were further splits and schisms, which I am not going to discuss further, illustrated below:

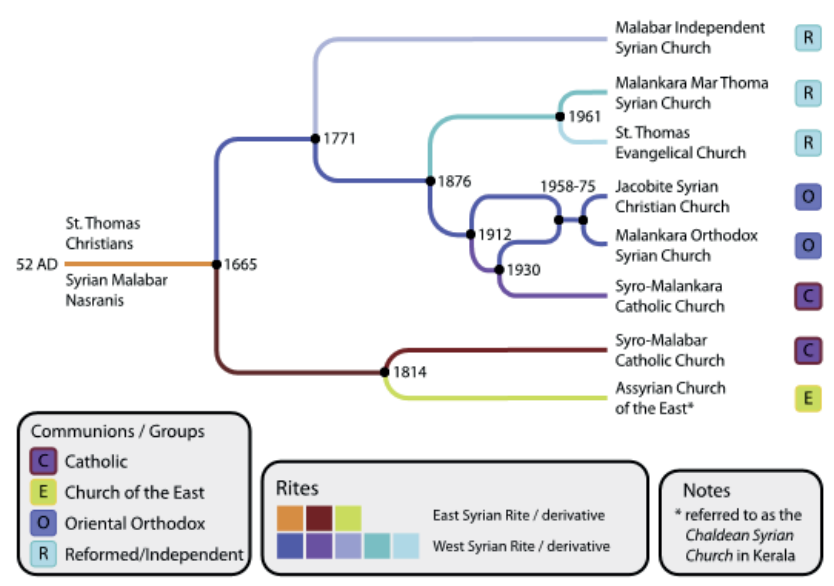

${ }^{20}$ Besides the condemnation of the Nestorian Church tradition, the adoption of the institution of priestly celibacy and the acknowledgement of the sole primacy of the Pope, all the suspect Syriac manuscripts were collected and burned although Syriac continued to be used as the liturgical language (A. S. Atiya, op. cit., p. 314; C. Baumer, op. cit., p. 239).

${ }^{21}$ Bishop Mar Ahatallah, appointed by the East Syrian Patriarch Mar Elias Shimun, was arrested, handed over to the Inquisition in Goa and died at stake in 1653 (A. S. Atiya, op. cit., p. 314; W. Baum, D. W. Winkler, op. cit., p. 113; C. Baumer, op. cit., p. 239).

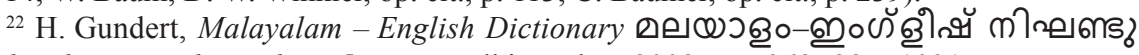
[malayālam - imglīs nighantu], New Delhi-Madras 2008, pp. 268, 285, 1031; வอமว๖०

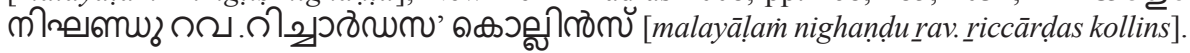
A Malayalam Dictionary, The Rev. Richard Collins. Third Edition. Revised and Enlarged by K. Shankara Pilla, New Delhi - Madras 1988, p. @nnd [139]. They swore not to recognize the Pope's authority and not to submit to the Jesuit dominance (A. S. Atiya, op. cit., p. 314; W. Baum, D. W. Winkler, op. cit., p. 115; C. Baumer, op. cit., p. 239). The disastrous consequences of the Jesuit activities caused the reaction of the Holy See; in 1657 Pope Alexander VII sent a new Carmelite mission to pacify the enraged Saint Thomas Christians. In 1663, when the Dutch conquered South India, all of the Catholic missionaries and Jesuit priests were expelled from Malabar (A. S. Atiya, op. cit., p. 315). 


\section{Liturgical differences}

Before the conclusive synod of Diamper the Saint Thomas Christians followed the East Syrian Eucharistic Liturgy. The 1599 revision of the rite in the Roman direction and the establishment of the Catholic Syro-Malabar Church after the 1653/1665 split indicated a long evolution of the former Nestorian liturgy. Although the rite of the Catholic Syro-Malabar Church was Latinised, the Syriac liturgical language was preserved, as well as the Chaldean structure of the Mass (qurbānā). ${ }^{23}$ The Congregation for the Propagation of the Faith (Sacra Congregatio de Propaganda Fide) printed the liturgical books for the Malabar Christians remaining in union with Rome. ${ }^{24}$ Some later adaptations were carried out during the pontificate of Pius XI in 1934. The most important change was the reinstatement of the original Eucharistic Liturgy drawing into the original East Syrian sources, deprived of the Latinised elements, which occurred in 1962. ${ }^{25}$

As mentioned above, the Orthodox Malankara Church embraced the Syro-Antiochean liturgy known as the liturgy of St. James (the Just). Considered to be the oldest preserved liturgy developed for general use in the Church, it assumed its final form in the $4^{\text {th }}$ century. The liturgy is noted for its developed hymnology. The author of those hymns was Jacob of Serugh, Syriac: حمحב" aic ya 'qū $\underline{b}$ srūga $\bar{y} y \bar{a}$ (451-521), called "the flute of the Holy Ghost." ${ }^{26}$ The liturgy is characterized by rich ritualistic performance (many gestures, lavish use of incense). ${ }^{27}$

\section{Syriac liturgy versus Malayalam liturgy}

Most Christian denominations, especially the Catholic rites, dropped Syriac as the language of church service in the second half of the $20^{\text {th }}$ century. ${ }^{28}$

\footnotetext{
${ }^{23}$ B. Nadolski, op. cit., vol. I., p. 38.

${ }^{24}$ The main liturgical books were: Ordo Chaldaicus Missae Beatorum Apostolorum, juxta ritum Ecclesiae Malabaricae, Rome 1774; Ordo Chaldaicus Rituum et Lectionum, Rome 1775; Ordo Chaldaicus ministerii Sacramentorum Sanctorum, Rome 1775. The later Ordo Baptismi adultorum juxta ritum Ecclesiae Malabaricae Chaldaeorum, Rome 1859 was a Syriac translation of the Roman order.

${ }^{25}$ The process of liturgical reform was initiated by Pope Pius XI. The restored liturgy was approved by Pope Pius XII in 1957 (B. Nadolski, op. cit., vol. I., p. 38; “The Nazrani” vol. 19 no. 11, New Delhi, November, 2009, http://thenazrani.org/archives27.htm).

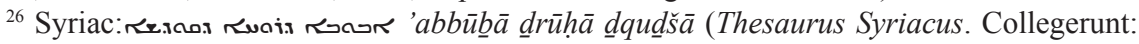
Stephanus M. Quatremere, Georgius Henricus Bernstein, G. W. Lorsbach, Albertus Jac. Arnoldi, Carolus M. Agrell, F. Field, Aemilius Roediger. Auxit, digessit, exposuit, edidit: R. Payne Smith, S.T.P., Tomus I: r LXXIX, p. 11).

${ }^{27}$ B. Nadolski, op. cit., vol. I., p. 39.

${ }^{28}$ Up until 1960's, a person to be ordained had to know Syriac just enough to read and understand the liturgy (Save Syriac http://nasrani.net/2007/11/10/save-syriac/\#identifier_3_245).
} 
A smooth transition from Syriac to Malayalam in the Catholic Syro-Malabar Church service was facilitated by a gradual restoration of the text of the Holy Qurbana by the Roman Commission (1957 in Latin; 1960 in Syriac; 1962 in Malayalam-Syriac). Though the text was basically in Malayalam, some prayers were in Syriac. ${ }^{29}$ All the Syriac prayers and religious texts were translated into Malayalam. The later discussions about the validity of the new liturgy version, and its further revisions, only speeded the switch-over from Syriac to Malayalam. ${ }^{30}$

The Syriac Orthodox Church also introduced Malayalam as her liturgical language. The Liturgy of St. James was also translated into Malayalam and currently, many Syriac prayers and hymns translated into Malayalam are used in all denominations. In the course of ceremonies some hymns are recited in Syriac.

The following hymn is a Malayam translation from Syriac: ${ }^{31}$

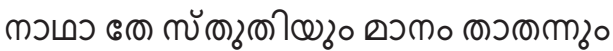

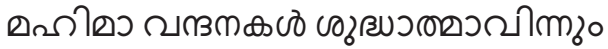

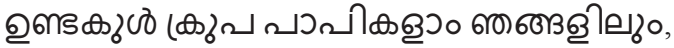

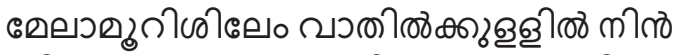

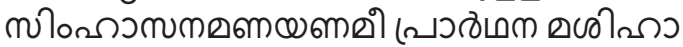

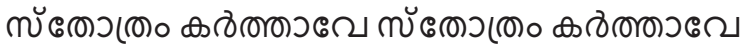

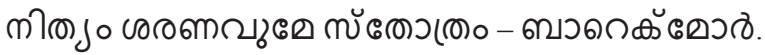

nāthā! tē stutiyum mānam tātannum

mahimā vandanakal śuddhātmāvinnum

uṇ̣̂ākul krupa pāpikalām ñan்ialilum,

mèlāmūriśalèm vātilkkullili nin

simhāsanamaṇaynamī prārthana maśihā!

stōtrai் karttāvēe! stōtrai் karttāvēe!

nityaì śaraṇavumē! stōtrai் - bārekmōr.

Praise to Thee, O Lord, to Thy Father Praise,

Worship, glory be to the Holy Ghost.

Grace and mercy be on us sinners all,

Opened be to us Zion's gates above

May our pleas be heard at the throne of Christ.

Praise to Thee, O Lord, Praise to Thee, O Lord,

Ever praise to Thee, Our hope. Barekhmor.

${ }^{29}$ A. Nariculam, Syro-Malabar Liturgy (http://mangalapuzha.wordpress.com/2009/08/28/ syro-malabar-liturgy/); K. P. M. Basheer, A sacred language is vanishing from State (http://www. thehindu.com/2008/08/11/stories/2008081164350500.htm).

${ }^{30}$ A. Nariculam, op. cit.

${ }^{31}$ Passion Week Wednesday Evening 2-3 (http://www.malankaraworld.com/Library/Prayers/ Joykutty/wedmorning.pdf). I have transliterated all the Malayalam and Syriac texts which are given usually in Malayalam characters. 
The subsequent Malayalam version of Syriac original, written with Malayalam characters: ${ }^{32}$

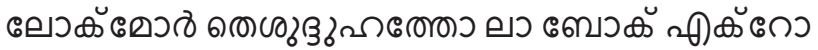

lōkmōr teśudduhattō lā bōk ekrōō

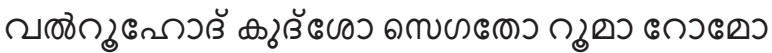

valrūhōd kudśo segatō rūumā rōmō

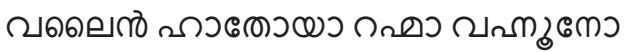

valain hātōyā rahmā vahnūnō

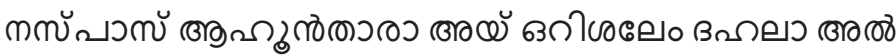

naspās āhūntārā ay orisílèm dahalā al

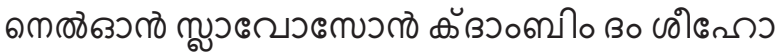

nelōn slāvōsōn kdāmbim dam śīhō

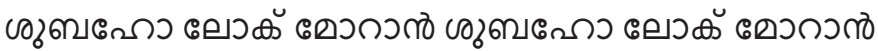

śubahō lōk mōrāan śubahō lōk mōrān

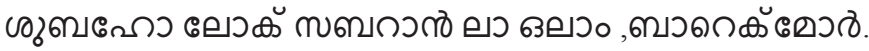

śubahō lōk sabarāan lā ōlām bārekmōr.

The Syriac text has been deformed. As I have not found the Syriac source of the text I present my attempt to recreate it:

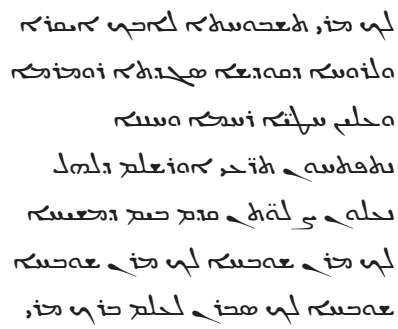

lāk mār tešbōḥtā labūk ’ 'iqqārāa

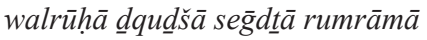

wa layn ḥațtāyē rahmōà wahnnānā

netpathōon tar 'ay 'ōrišlem dalhal

ne 'lōn șalwātan quāam bệm damšìh

šuḅha lāk māran šubhā lāk māran

šubhạ lāk sabran l'ālam barrek mār

The hymn consists of seven isosyllabic verses (10 syllable each).

\footnotetext{
${ }^{32} \mathrm{Ibid}$. The pronunciation is adopted to the Malayalam phonetic system.
} 


\section{The Bible in Malayalam}

The Protestant Kerala Syrians started using Malayalam as their liturgical language in the late $19^{\text {th }}$ century. The first printed Malayalam Bible, translated from Syriac by two scholars, Kayamkulam Philipose Ramban and Pulikottil Ramban, assisted by Subbayya Pillay, was published in 1811 by Dr. Claudius Buchanan in Bombay. Known as the Ramban Bible it contained only the four Gospels. The New Testament was first published in 1829. The first complete Malayalam Bible was translated, printed and released by Benjamin Bailey, the Anglican missionary, in 1841 with the help of Moses Essarfathi, a Hebrew scholar, and Vydyanadha Iyer, a Sanskrit pundit, together with the English-Malayalam scholar Chandhu Menon. ${ }^{33}$ Under the Anglican influence, in the late $19^{\text {th }}$ century, the Protestant Syrians started using Malayalam as their liturgical language. Malankara Mar Thoma Church uses the reformed liturgy in Malayalam.

The Kerala Catholic most popular Manikkathanar's version of the New Testament was published only in 1940. The whole Bible was translated by Rev. Fr. Thomas Moothedan on the basis of the Syriac Peshitta and the Latin Vulgate, and published in $1963 .{ }^{34}$

\section{A short dictionary of the Malayalam words and phrases of Syriac origin}

I have arranged the words according to the order of the Malayalam alphabet. I have chosen the most common words and phrases, which are to be found in the dictionaries and in the liturgical books. Besides the English-Malayalam ${ }^{35}$ and Malayalam-English dictionaries mentioned previously, I have used mainly the latest Sokoloff's version of the Brockelmann's Syriac lexicon to explain the meanings of the Syriac words and phrases.$^{36}$ I used the traditional transcription

${ }^{33}$ The Centenary of the Malayalam Bible

(http://www.keralabrethren.net/boardkb/view.asp?id=2119\&forum=General); Exhibition traces evolution of Malayalam Bible, "The Hindu" (http://www.hindu.com/2011/06/15/stories/2011061550740200.htm);

${ }^{34}$ A new venture in Bible mission in Kerala, Kerala Catholic Bible Society (http://www. keralabiblesociety.com/pages/en/BibleCommission.html).

${ }^{35}$ T. Zacharias, An English-Malayalam Dictionary Đov̆ imgḹṣ malayālạm śabdakōśam, Mangalore 1907.

${ }^{36}$ M. Sokoloff, A Syriac Lexicon. A Translation from the Latin, Correction, Expansion, and Update of C. Brockelmann's Lexicon Syriacum, Piscataway, New Jersey 2009. Other sources

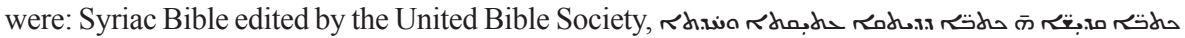

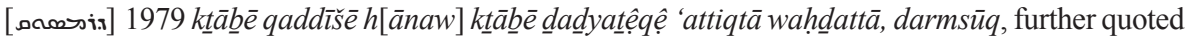
as: Biblia Syriaca, op. cit.; C. Brockelmann, Syrische Grammatik mit Paradigmen, Literatur, Chrestomathie und Glossar, Leipzig 1981; Lexicon to the Syriac New Testament (Peshitta). With copious references, dictions, names of persons and places and some various readings found in the 
of Syriac preserving the double consonants and historical system of vowels. ${ }^{37}$ The reader will easily recognize whether a given Malayalam form comes from the West or East Syriac tradition.

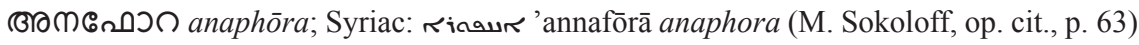
৫ூฮॅ๑றி almani (H. Gundert, op. cit., p. 58, T. Zacharias, op. cit., pp. 458, 901); Syriac: حلیālmānāyā secular, lay, earthly, wordly (M. Sokoloff, op. cit., p. 1105)

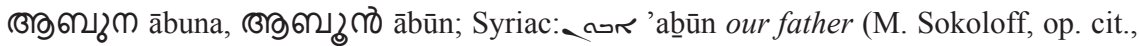
p. 1; Brockelmann 1981: 153-154)

৫ூூவி Syriaca, op. cit., part III, p. 345)

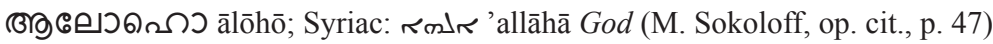

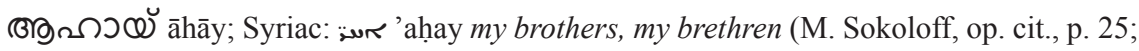
Biblia Syriaca, op. cit., part III, p. 203)

๑)கัดைว ekbo; Syriac: حمح 'eqūā type of hymn (song of continuation) (M. Sokoloff, op. cit., pp. 1128-1129)

๑)ด(৫) etro; Syriac: ritir 'atrāā place; opportunity, time (M. Sokoloff, op. cit., p. 112)

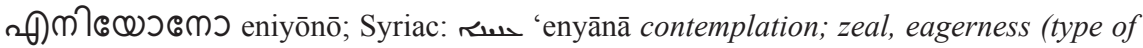
devotional song) (M. Sokoloff, op. cit., p. 1117)

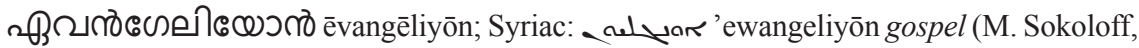
op. cit., pp. 17-18)

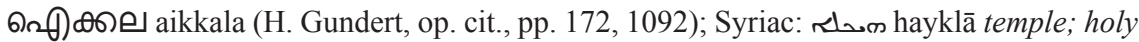
place in the temple (M. Sokoloff, op. cit., pp. 340-341)

Curetonian, Sinaitic palimpsest, Philoxenian \& other MSS by William Jennings, M. A. Revised by Ulric Gantillon, M. A., Ancient Language Resources, Ancient Language Resources, Eugene, Oregon 2001 (further quoted as: W. Jennings, op. cit.). Thesaurus Syriacus. Collegerunt: Stephanus M. Quatremere, Georgius Henricus Bernstein, G. W. Lorsbach, Albertus Jac. Arnoldi, Carolus M. Agrell, F. Field, Aemilius Roediger. Auxit, digessit, exposuit, edidit: R. Payne Smith, S.T.P., Tomus I: $u_{n}, \downarrow$ w

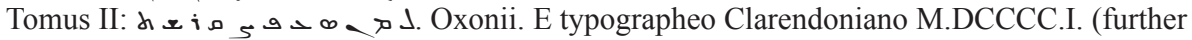
quoted as: R. Payne Smith, op. cit., vol. I or vol. II).

${ }^{37}$ Although the written Syriac language remained the same, there developed two different pronunciations of Syriac. The Eastern, which is essentially more archaic, came to be used by members of the Church of the East, mainly inhabiting Iraq and Iran. The Western way of pronunciation is followed by the Maronites and the Syrian Orthodox living in Syria and the eastern part of Turkey. The most obvious difference between the two consists in the pronunciation of original $\bar{a}$ and $\bar{o}$ : the Western alter them respectively to $\bar{o}$ and $\bar{u}$. Additionally, the historical $\hat{e}$ is changed to $\bar{l}$. The Eastern pronunciation preserves all the mentioned vowels as well as the doubling of the consonants in opposition to the Western pronunciation (S. Brock, An Introduction to Syriac Studies [in:] J. H. Eaton, ed., Horizons in Semitic Studies: Articles for the Student, University Semitics Study Aids 8, Birmingham 1980, p. 13; Th. Nöldeke, Compendious Syriac Grammar, Winona Lake, Indiana 2001, pp. 5, 7, 9, 13-14). 


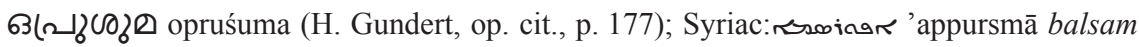
(M. Sokoloff, op. cit., p. 84)

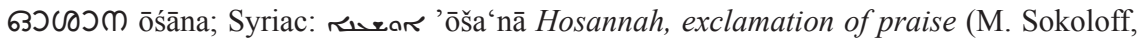
op. cit., p. 23)

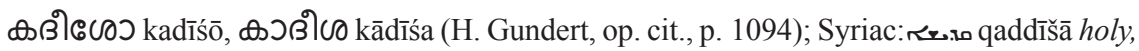
sacred (M. Sokoloff, op. cit., p. 1316)

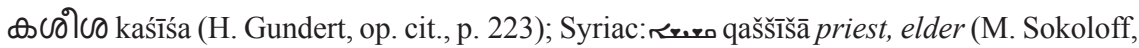
op. cit., p. 1419) doubling

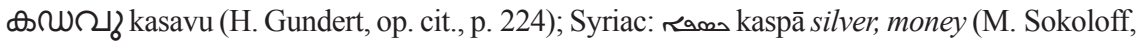
op. cit., p. 641)

கெெலுつ kaittā; Syriac: م. مayțā summer (M. Sokoloff, op. cit., p. 1361)

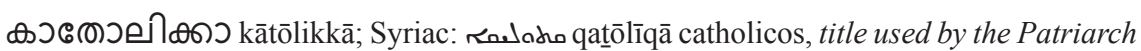
of certain Eastern Churches (M. Sokoloff, op. cit., p. 1421)

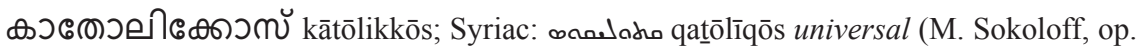
cit., p. 1421)

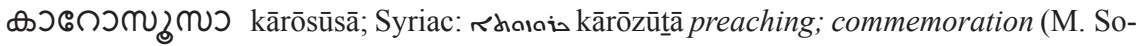
koloff, op. cit., p. 647)

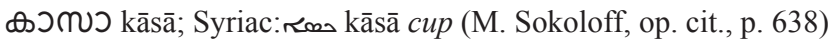

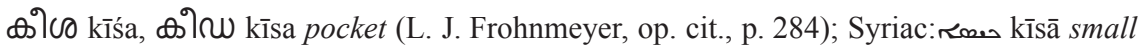
sack (M. Sokoloff, op. cit., p. 620)

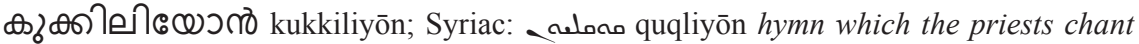
while circling around the altar in procession (M. Sokoloff, op. cit., p. 1342)

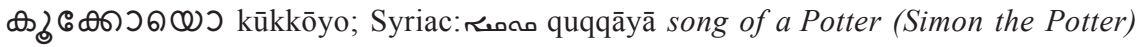
(R. Payne Smith, op. cit., vol. II, p. 3557)

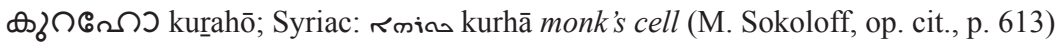

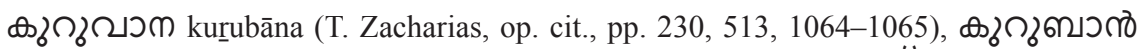

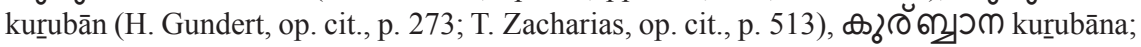
Syriac: مurbānā sacrifice, the Eucharist (M. Sokoloff, op. cit., p. 1343)

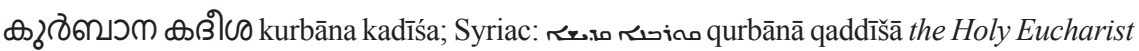
(M. Sokoloff, op. cit., pp. 1316, 1343)

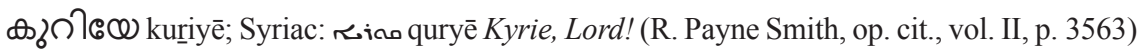

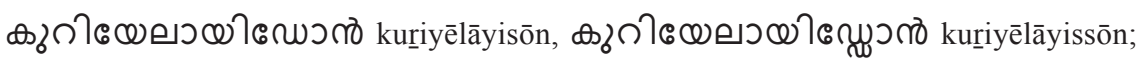
Syriac: مaryē leysōn Kyrie eleison, Lord, have mercy! (R. Payne Smith, op. cit., vol. II, p. 3563)

कூ乃ß

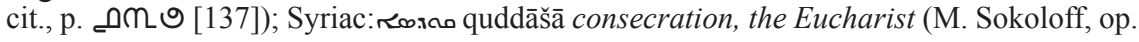
cit., p. 1325)

கூஷேว church (M. Sokoloff, op. cit., p. 1325) 
கேכேேつ kōlō; Syriac: ملع qālā musical tune, mode; sound (M. Sokoloff, op. cit., p. 1367)

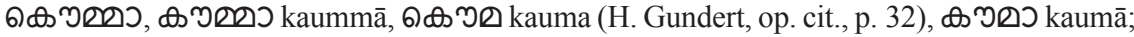

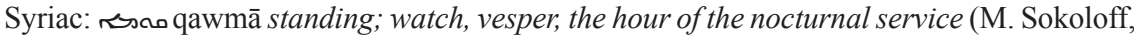
op. cit., pp. 1333-1334)

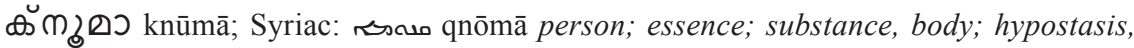
substantive reality (M. Sokoloff, op. cit., p. 1380)

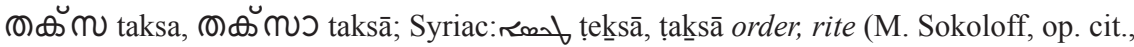
p. 1380)

வூ ேேวளைد tūyōbo; Syriac: op. cit., p. 516)

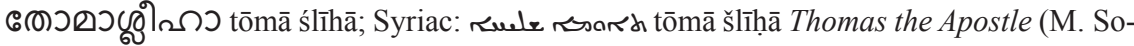
koloff, op. cit., p. 1564; Biblia Syriaca, op. cit., part III, p. 11)

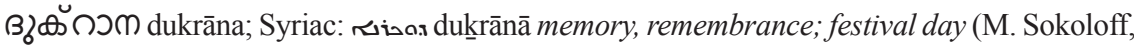
op. cit., p. 281)

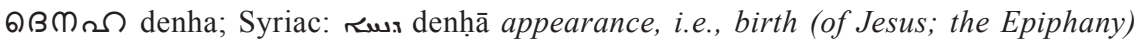
(M. Sokoloff, op. cit., p. 313)

m(m) Syriac: nāṣrāyā Nazarene; Christian (M. Sokoloff, op. cit., p. 942)

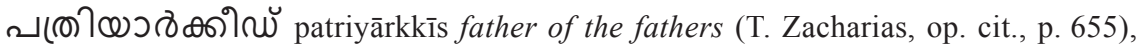

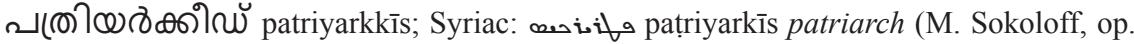
cit., p. 1184)

๖னூஃெ๐ல pardaisā garden; esp. of Eden, i.e., Paradise (M. Sokoloff, op. cit., p. 1228)

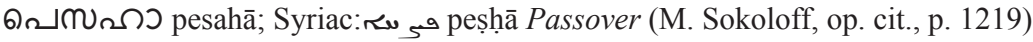

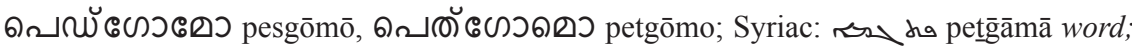
sentence; verse (M. Sokoloff, op. cit., p. 1264)

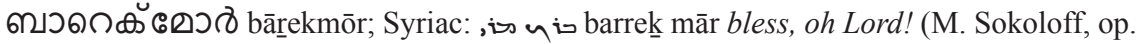
cit., pp. 190, 823)

ஸிดつ bīma; Syriac: כـēmā tribunal, judgment seat (M. Sokoloff, op. cit., p. 141)

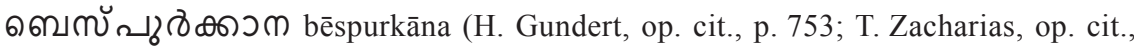
p. 458); Syriac:du r wêt purqānā place of redemption, purgatory (M. Sokoloff, op. cit., pp. 144, 1172)

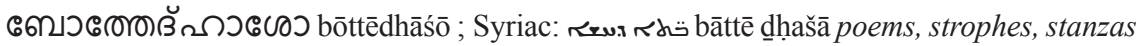
of the Passion (M. Sokoloff, op. cit., pp. 145, 497)

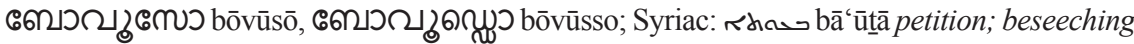
(M. Sokoloff, op. cit., p. 169)

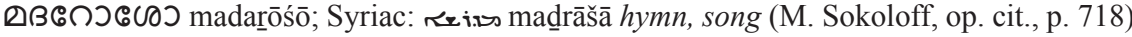

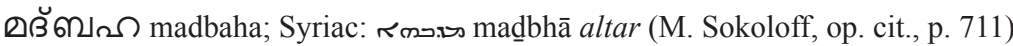




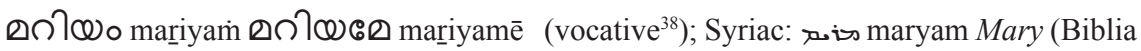
Syriaca, op. cit., part III, p. 1)

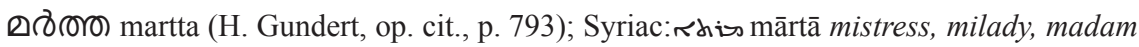
(M. Sokoloff, op. cit., pp. 839-840)

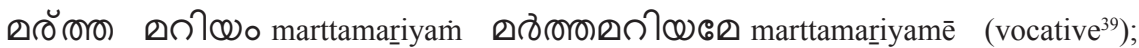
Syriac: sis mārt maryam My Lady Mary (M. Sokoloff, op. cit., pp. 839-840; Biblia Syriaca, op. cit., part III, p. 1)

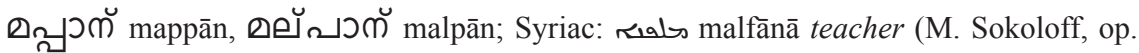
cit., p. 774)

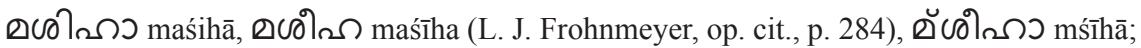
Syriac: ruess mšịhāā Messiah, Christ (M. Sokoloff, op. cit., p. 845)

๑ (M. Sokoloff, op. cit., pp. 393, 845)

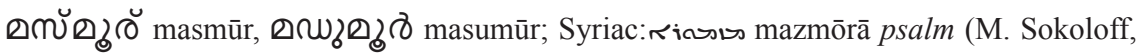
op. cit., p. 735)

๑ว Sokoloff, op. cit., p. 802)

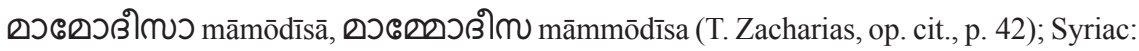
Rh.osus ma'mōdīitā baptism (M. Sokoloff, op. cit., p. 802)

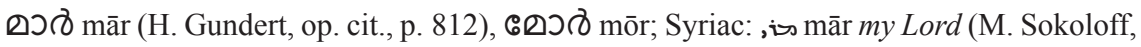
op. cit., pp. 823-824)

๑วกวัॅ mārān (L. J. Frohnmeyer, op. cit., p. 284); Syriac: is māran our Lord (M. Sokoloff, op. cit., pp. 823-824)

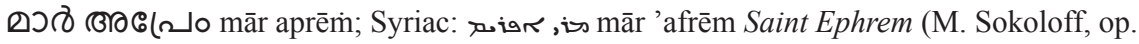
cit., pp. 823-824; (R. Payne Smith, op. cit., vol. I, pp. 351-352)

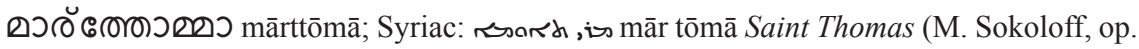
cit., pp. 823-824; Biblia Syriaca, op. cit., part III, p. 11)

๑วอวவว mālākhā, صวอدவ mālākha (L. J. Frohnmeyer, op. cit., p. 284); Syriac: mallak̄ā messenger; angel (M. Sokoloff, op. cit., p. 764)

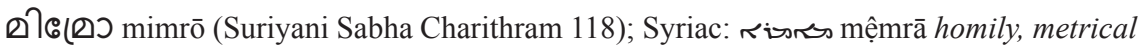
homily (M. Sokoloff, op. cit., pp. 701-702)

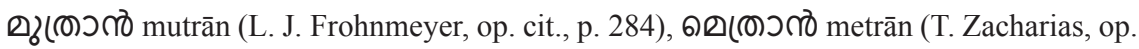
cit., p. 530); Syriac: _ ił mītrān metropolitan (M. Sokoloff, op. cit., p. 752)

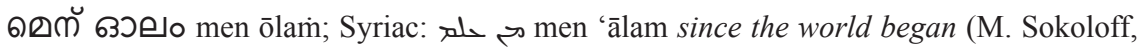
op. cit., p. 764; W. Jennings, op. cit., p. 164)

๑ெวலிஷ๒ว moriyo; Syriac: ๔is māryā God, Lord; Jesus (M. Sokoloff, op. cit., p. 823)

${ }^{38}$ T. Zacharias, op. cit., pp. VI-VII.

${ }^{39}$ Ibid. 


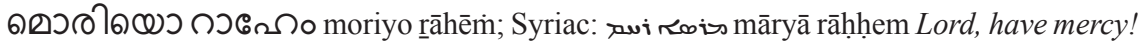
(M. Sokoloff, op. cit., pp. 823, 1456)

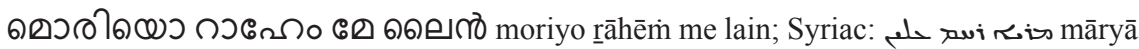
rāḥhem 'layn Lord, have mercy upon us! (M. Sokoloff, op. cit., p. 823, 1456)

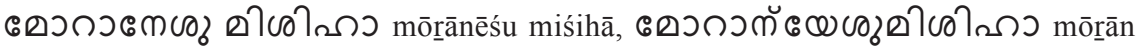

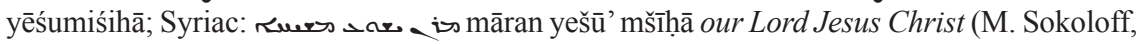
op. cit., pp. 823, 845; R. Payne Smith, op. cit., vol. I, p. 1638)

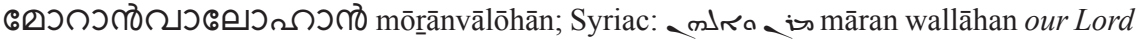
and our God (M. Sokoloff, op. cit., pp. 47, 823)

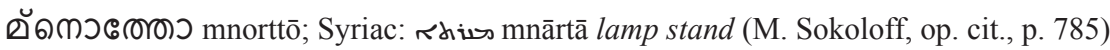

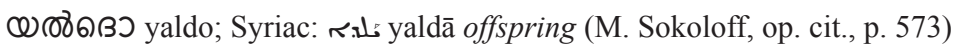

மேைర yēśu; Syriac: ras yešū' Jesus (R. Payne Smith, op. cit., vol. I, p. 1638)

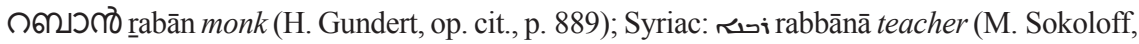
op. cit., p. 1429)

กगบ rāāsa the most solemn form of Mass in the Chaldean rite); Syriac: кiri rāzā mystery, symbol; sacrament (M. Sokoloff, op. cit., p. 1424)

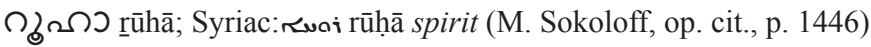

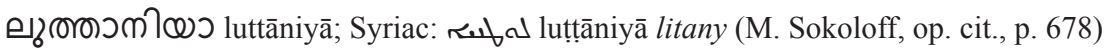

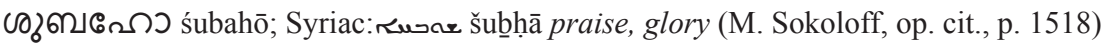

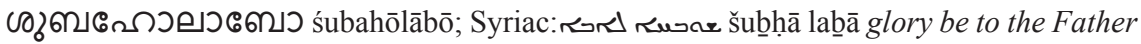
(M. Sokoloff, op. cit., pp. 1, 1518)

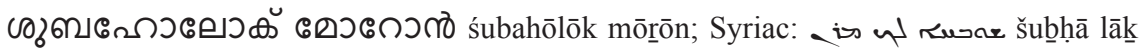
māran glory be to you, our Lord (M. Sokoloff, op. cit., pp. 823, 1518)

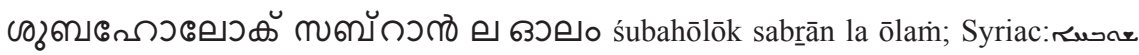

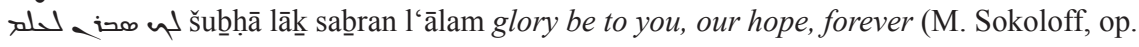
cit., pp. 764, 965, 1518)

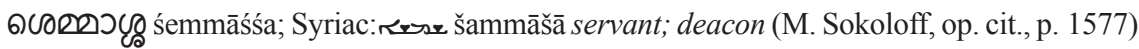

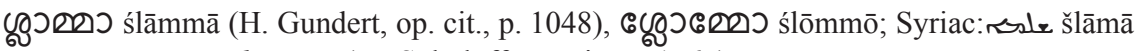
peace; greeting, salutation (M. Sokoloff, op. cit., p. 1567)

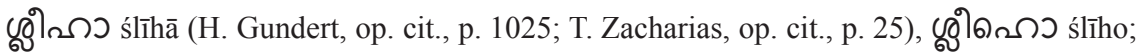
Syriac:ruele šlīhāā apostle (M. Sokoloff, op. cit., p. 1564)

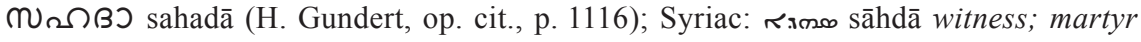
(M. Sokoloff, op. cit., p. 973)

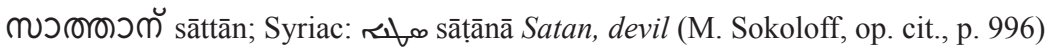

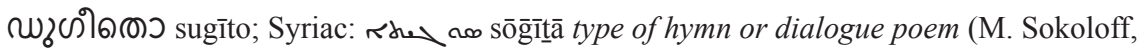
op. cit., p. 976)

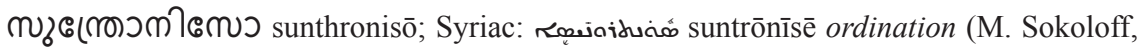
op. cit., p. 985) 


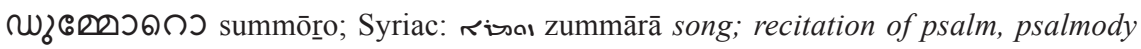
(M. Sokoloff, op. cit., p. 373)

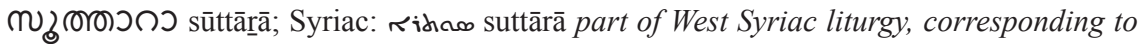
latinate Compline (M. Sokoloff, op. cit., p. 992)

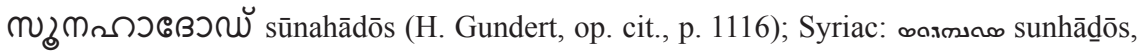
œ:х๐ก sunād̄ōs synod (M. Sokoloff, op. cit., p. 983)

ஷயßกว sedarāā; Syriac: ₹iroo sedrā order; sedra, kind of hymn (M. Sokoloff, op. cit., p. 972)

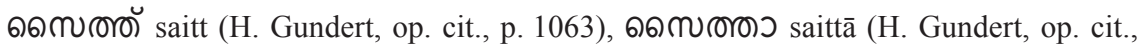
p. 1116); Syriac: К丸ь zaytā olive (M. Sokoloff, op. cit., p. 379)

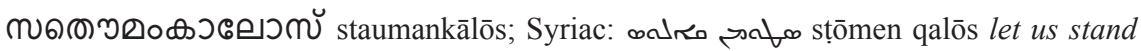
well (R. Payne Smith, op. cit., vol. II, p. 2598)

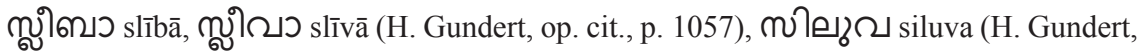

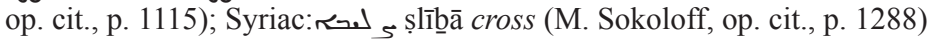

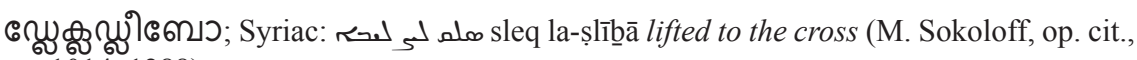
pp. 1014, 1288)

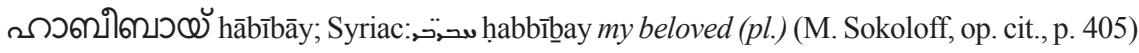

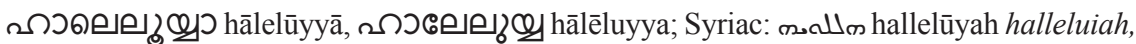
praise the Lord! (R. Payne Smith, op. cit., vol. I, pp. 1010-1011)

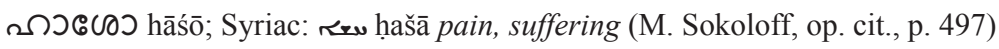

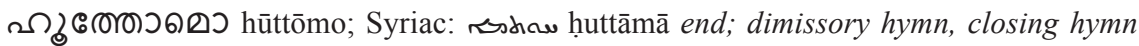
(M. Sokoloff, op. cit., p. 436)

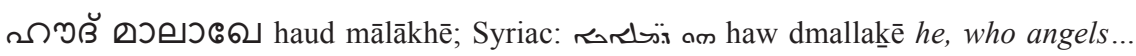
(Brockelmann 1966: 172; M. Sokoloff, op. cit., p. 764)

Sources of Malayalam words

The Common Prayers of the Jacobite Syrian Orthodox Church (http://carteretchurch.com/ prayers.aspx).

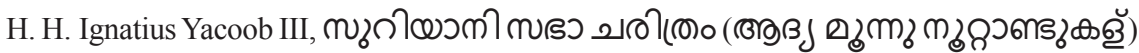
Suriyani Sabha Charithram (History of the Syrian Church-First Three Centuries), Chingavanam 1948 (http://moradaistudycenter.org/booksonline_21.html).

Intercessions to Mary, St. Eldho etc. (http://stmaryschurchkandanad.org/prayer.php).

Liturgy Texts of Knanaya Catholic Region (http://www.knanayaregion.us/liturgy_texts.htm).

The Malankara Orthodox Syrian Christian's Holy Liturgy of Passion Week from Hosanna to Kymtho (Easter). (In Malayalam, English Transliteration \& English Translation). Compiled by St. Gregorios Indian Orthodox Church Mississauga, Ontario 2011 (http://www.icon.org. in/misc/FullPassionWeek2.pdf).

Syrian Orthodox Prayers (http://www.malankaraworld.com/library/Prayers/).

৫ூวாேேวก anaphōra (http://ml.wikipedia.org/wiki/\%E0\%B4\%85\%E0\%B4\%A8\%E$0 \% \mathrm{~B} 4 \% \mathrm{AB} \% \mathrm{E} 0 \% \mathrm{~B} 5 \% 8 \mathrm{~B} \% \mathrm{E} 0 \% \mathrm{~B} 4 \% \mathrm{~B} 1$ ) 


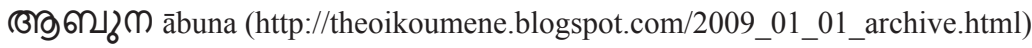
லூதகூJMー ākamānam (http://theoikoumene.blogspot.com/2009_01_01_archive.html). क్రిరుગm kurbāna (http://ml.wikipedia.org/wiki/\%E0\%B4\%95\%E0\%B5\%81\%E0\%B5\%BC\%E0\%B4\%AC\%E0\%B4\%BE\%E0\%B4\%A8)

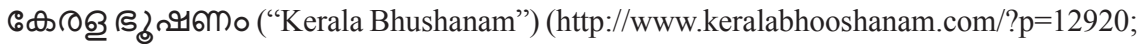
http://www.keralabhooshanam.com/?p=69233)

๑วேேวßிก māmmōdīsa (http://ml.wikipedia.org/wiki/\%E0\%B4\%AE\%E0\%B4\%BE\%E0\%B4\%AE $\%$ E0\%B5\%8D $\%$ E0\%B4\%AE $\%$ E0\%B5\%8B $\%$ E0\%B4\%A6\%E0\%B5\%80\%E$0 \% \mathrm{~B} 4 \% \mathrm{~B} 8)$ 